\title{
静止軌道の摂動の簡易理論*1 \\ Simple Theory of Geosynchronous-Orbit Perturbations
}

\author{
川 瀬 成 一 郎*2 \\ Sei-ichiro KAWASE
}

Key Words : Station Keeping, Solar Radiation Pressure, Solar Gravity, Lunar Gravity

\begin{abstract}
A simple perturbation theory is introduced for modeling geosynchronous orbits. The theory uses diagrammatic representations of orbits, and derives the perturbations in a direct manner without using differential equations. Perturbations of major importance are derived, including satellite-longitude changes due to the earth's asymmetric shape, orbital eccentricity increase due to the sun-radiation pressure, and orbital plane inclination due to the sun/moon attraction. The theory clarifies the physical/geometrical meaning of the perturbations while using minimal mathematical analysis.
\end{abstract}

\section{1.は じめ に}

静止軌道に衛星を投入した後，継続的に静止を保とうと すると，軌道を定期的に修正しなければならない，もしも 衛星に衝く力か理想的な力, すなわち地球の中心に向かう 逆 2 乗則の力だけであったなら，いったん静止させた衛星 は軌道を修正しなくても静止を保ち続ける．しかし現実に は理想的な力のほかに, 弱いながらも徐々に軌道を変える 力が㗢く. そ光のような力を摂動力と呼び, 静止軌道の衛星 に働く摂動力としては, 月や太陽による引力 , 太陽の光が 及ぼす圧力, 地球の質量分布か球対称でなく歪んでいるこ とに伴う力 , が代表的にあげられる .これらの力が軌道の 変化,つまり摂動を引きおこし, 弚れは時間の経過につれ て増大していくことから，上記のように定期的な軌道の修 正が必要になる.

衛星の軌道に生じる捸動については，理論的に解析する 手法が追究されてきた ${ }^{1,2)}$. 光の理論では, 軌道を表す 6 要 素を光れ時間の関数とおいて, 関数が摂動力の作用で どのように変わっていくか解析する.解析には高度な数学 手法が用いられ，弚れをたどるには専門的な修練をつまな ければならない，もしも専門の違う分野，例えば通信や観 測ミッションの方面において, 軌道の摂動は何故, どのよ うに生じるのかと問いか現れたようなとき, 上記の理論を 兴のまま答えとするのは必ずしも適切といえないであろう． 弚ういう問いに分かりやすく，定量的に，しかも物理的意 味を明示して答える方法はないものであろうか．

本報告は，対象を静止軌道に限るなら，きわめて簡易な 理論によって捸動を扱えることを示す．上に記した代表的 な摂動力について, 光れ光れ軌道か変化する法則を簡素な

\footnotetext{
*1 (C) 2007 日本航空宇宙学会

平成 19 年 4 月 20 日原稿受理

*2 NICT 鹿島宇宙技術センター
}

数学手法だけで導く. 静止軌道における摂動を簡易に扱う 試みには先例があるが3)，光こでは線型近似に基づく微分 方程式を用いていた . 本報告では, 図式的な解法の助けを かりて，より一層の分かりやすさを目指す . 本報告は, 新 しい理論内容を示すものではないが, 既知の現象について 可能なかぎり平易な解釈を試みる .

\section{2. 準備：軌道の形とその変化}

衛星軌道の長半径を $a$, 離心率を $e$ とすると, 衛星の公 転角 $\theta$ に対する径 $r$ は次の公式で与えられる.

$$
r=\frac{a\left(1-e^{2}\right)}{1+e \cos \theta}
$$

静止軌道の離心率は小さいから,$e$ の一次の項までをとれ ば，(1)式を次のように近似できる .

$$
r=a-a e \cos \theta
$$

さて第 1 图では, 半径 $a$ の円周上の A に衛星があり，円 の中心 $\mathrm{O}_{1}$ は地心すなわち原点 $\mathrm{O}$ から $a e$ だけ変位してい て, 弚の変位は小さいと仮においた，衛星から $\mathrm{OO}_{1}$ を見

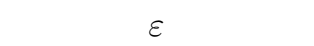

$$
r=a-a e \cos (\theta-\varepsilon)
$$

が成りたつ. 角 $\varepsilon$ の大きさは $e$ を越えないから，(3) 式に おいて $e$ の一次の項までをとれば $r=a-a e \cos \theta$ となっ て, (2) 式に一致する.よって離心率が小さい軌道は, 光の 形が円で , 中心の位置が

$$
D=a e
$$

だけ変位したものと見なしてよい.つまり半径 $a$ と, 中心 变位 $D$ の大きさ及び方向を与えると, 面内における軌道 が規定される.(従って以下では軌道長半径を単に半径と 


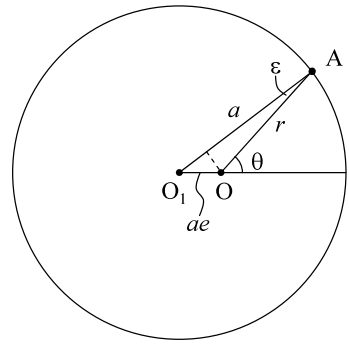

第 1 図近円軌道の形

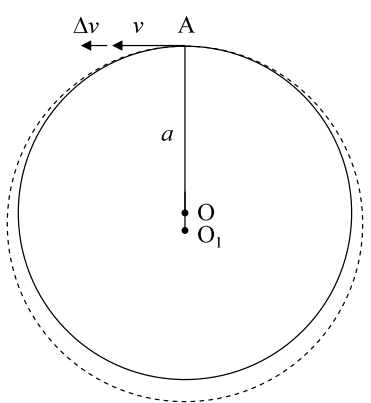

第 2 图 進行方向増速の効果

呼引:.)

第 2 図において, 半径 $a$ の円軌道を衛星が速度 $v$ で周 回しているとする．衛星が $\mathrm{A}$ 点にきた瞬間に，進行方向へ 小さい増速 $\Delta v$ を与えると，軌道はどう変わるであろうか． 増速にともない衛星の運動エネルギは

$$
\Delta E=\Delta\left(\frac{v^{2}}{2}\right)=v \Delta v
$$

だけ増す．ただしエネルギとは衛星の単位質量あたりのエ ネルギを指し, この扱い方は以下でも同樣とする.一方 , 半 径 $a$ の軌道に固有のエネルギは

$$
E=-\frac{\mu}{2 a}
$$

で与えられる ( $\mu$ は万有引力定数 $\times$ 地球質量). 軌道の半 径が $\Delta a$ 増せば，エネルギは

$$
\Delta E=\frac{\mu}{2 a^{2}} \Delta a
$$

だけ増す．よって (5) 式と (6) 式を等しいとおけば

$$
\Delta a=2 a \frac{\Delta v}{v}
$$

となって，増速 $\Delta v$ は半径を $\Delta a$ だけ増大させる . 新しい 軌道は点 $\mathrm{A}$ を通るから, 弚の中心は $\mathrm{O}$ から $\mathrm{O}_{1} へ \Delta a$ だ け変位していなければならない，つまり変位量 $\mathrm{OO}_{1}$ は

$$
D=2 a \frac{\Delta v}{v}
$$

と表せる. 半径 $\mathrm{O}_{1} \mathrm{~A}$ は速度 $v$ に垂直でなければならない から， $\mathrm{O}_{1}$ は直線 $\mathrm{AO}$ 上にある.

次に第 3 図では, 半径 $a$ の円軌道を衛星が速度 $v$ で周

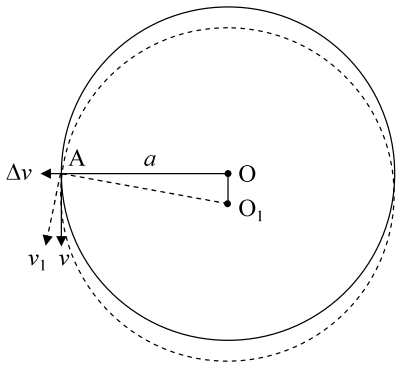

第 3 図 半径方向増速の効果

回しているとして, 衛星が $\mathrm{A}$ 点にきた瞬間に半径方向への 増速 $\Delta v$ を与えたとする . 増速が小さければ，速度の大き さは変わらずに方向だけか変わる，従って運動エネルギは 変わらないから, 軌道の半径も変わらない. 中心は $\mathrm{O}_{1}$ へ 変位して, $\mathrm{OO}_{1}$ は $\mathrm{AO}$ に垂直になる。増速直後の速度 $v_{1}$ の向きは, 半径 $\mathrm{O}_{1} \mathrm{~A}$ に垂直でなければならないから, 変 位量 $\mathrm{OO}_{1}$ は

$$
D=a \frac{\Delta v}{v}
$$

に等しい．

以上で, 軌道面内の摂動を導く準備ができた .

\section{3. 地球の形による摂動}

地球を赤道面に沿って輪切りにすると，切り口の形はわ ずかに真円から歪んで，楕円形を示す . 切り口に対して衛 星が第 4 図のような配置にあるとすると，衛星に働く地球 の引力の向きは, 張り出した B 部の質量の作用によって, 地心 O からわずかに逸れる. 兴の結果, 衛星には進行方向 に力 $F$ が衝く .もしも衛星がB 部の真上にあれば $F$ は零 になるが，日本付近では東経 162 度が光れに該当する．ま たは衛星が B 部から 90 度はなれた所の真上にある場合に も $F$ は零になる .このように力 $F$ は衛星か清争止する場所 に応じて定まり，衛星が静止を保つなら $F$ の大きさも一定 としてよい.ここで注意として, 力 $F$ は衛星の単位質量あ たりに働く力を指し，数値としては加速度に相当する . こ の扱い方は以下でも同樣とする .

さて，ある正の值が力 $F$ に与えられたとして，軌道の 変化を第 5 図により調べよう. 半径 $a$ の円軌道を衛星が速 度 $v$ で周回しているとする . 衛星が (1) の位置にあるとき， 力 $F$ か時間 $\Delta t$ のあいだ㗢くと $F \Delta t=\Delta v$ という増速 が生じるから，(8) 式に従って中心の变位 $D$ が図中の $\left(1^{\prime}\right)$ のように生じる . 衛星が (2)，(3) と進むにつれて，中心の 変位は $\left(2^{\prime}\right),\left(3^{\prime}\right)$ のように積算されていって, 弚の軌跡は 破線のように円を描く(円は誇張されていて，実際には小 さい) . 衛星が 1 周回したときに , 中心の位置は元にもど り，さらに周回が進むとき中心位置の動きは同じ円周をた どる.よって離心率は一定の限度内にとどまり，永年的に 増大することはない, 一方, 軌道半径は (7) 式に従い, 時 間 $\Delta t$ のあいだに

$$
\Delta a=\frac{2 a}{v} \Delta v=\frac{2 a}{v} F \Delta t
$$


だけ増大する．よって軌道半径 $a$ は一定の率

$$
\dot{a}=\frac{2 a}{v} F
$$

で増大していく(第 6 図 ; 実線の $a$ ). 半径が $\Delta a$ 増すと, 衛星の公転角速度 $\omega$ は

$$
\Delta \omega=-\frac{3 \omega}{2} \frac{\Delta a}{a}
$$

だけ変わる.地球上で衛星の東経を測って $\lambda$ と記すと， $\Delta \omega$ は $\dot{\lambda}$ に生じる変化にほかならない .つまり

$$
\Delta \dot{\lambda}=\Delta \omega
$$

とおけるから，(11) 式と (10) 式によって

$$
\Delta \dot{\lambda}=-\frac{3 \omega}{v} F \Delta t
$$

さらに $v=a \omega$ を用いて

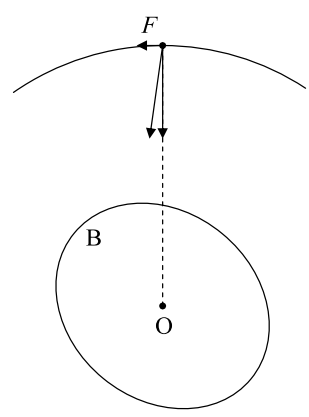

第 4 図＼cjkstart地球の形による摂動力

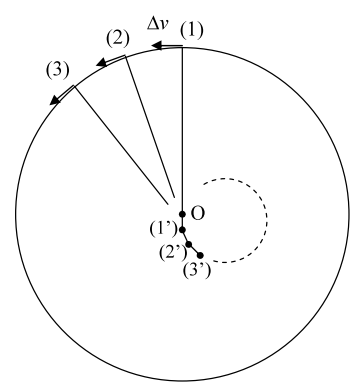

第 5 図 進行方向増速の効果
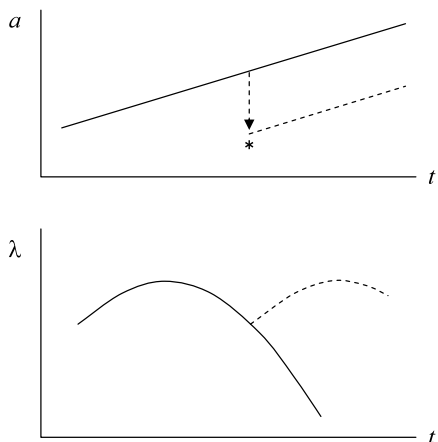

第 6 図＼cjkstart衛星経度の捸動

$$
\ddot{\lambda}=-\frac{3}{a} F
$$

となる . この式の中で, 半径 $a$ は時間とともに変わるが, 产の変わる範囲は, 静止を保っている衛星では高々 $10 \mathrm{~km}$ 程度にすぎないから , 公称值として $a=42165 \mathrm{~km}$ とおい ても誤差は無視できる.よって経度 $\lambda$ は，時間とともに 2 次カーブを描いて動く(第 6 图; 実線の $\lambda$ ). 例として , 日本付近では東経 120 度付近において $F$ の大きさが最大 の $0.065 \times 10^{-3} \mathrm{~mm} / \mathrm{s}^{2}$ になり，このとき $\ddot{\lambda}$ の大きさは $0.0020 \mathrm{deg} / \mathrm{day}^{2}$ に等しい.

\section{4. 太陽光の圧力による摂動}

第 7 図に描くように, 半径 $a$ の円軌道を衛星が速度 $v$ で 周回しているとする . 向かって右側のほうに太陽があると すると，弚の光の圧力は衛星に $F$ という力を及ぼす . は じめに仮定として, 力 $F$ は大きさも方向も変わらないと おく.

力 $F$ か時間 $\Delta t$ のあいだ働くと $F \Delta t$ という増速を生じ るが, 弚の半径方向の成分についてはじめに考える . 図中 で衛星が (1) の位置にあるとき, 半径方向の増速成分は

$$
\Delta v=F \Delta t \cos \theta
$$

に等しい. (便宜上, 衛星の公転角 $\theta$ を, 力 $F$ が㗢く方向 を延長した先から測った .) すると第 3 図に見たと同じメ カニズムによって, 中心は $\mathrm{O}$ から $\mathrm{O}_{1}$ に変位し, 兴の変位 の発生量は

$$
\Delta D=a \frac{\Delta v}{v}=\frac{a F}{v} \cos \theta \Delta t
$$

に等しい. 定数を

$$
K=\frac{a F}{v}
$$

と記すと, 変位 $D$ の時間にともなう成長率を

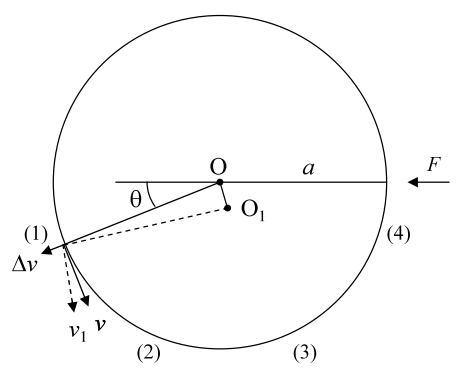

第 7 図 太陽光圧力 (半径成分) の効果

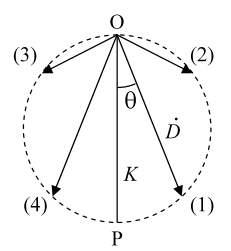

第 8 図 中心变位の成長率 


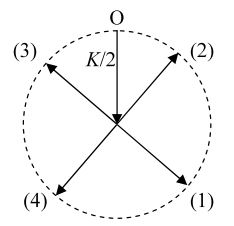

第 9 図 成長率ベクトルの分解

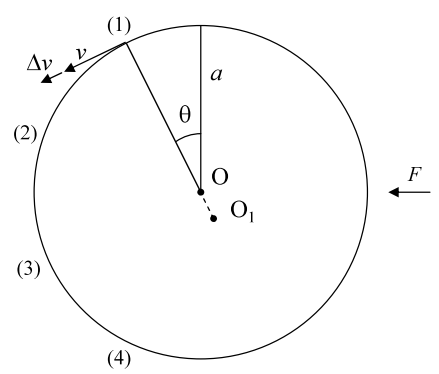

第 10 図 太陽光圧力 (進行成分) の効果

$\dot{D}=K \cos \theta$

と表せる .この成長率を，向きをもつべクトルとして表す と第 8 図の (1) に相当し, ベクトルの先端は, 長さ $K$ の線 分 $\mathrm{OP}$ を直径とした円の周上にある. 第 7 図にて衛星の位 置が (2)，(3)，(4) と進むと，第 8 図にてべクトルの先端 は (2)，(3)，(4) と進む．(注意として，衛星位置が (2) か ら (3) へ移るさいには増速 $\Delta v$ の符号か変わるので, 成長 率べクトルは第 8 図で (2) から (3) のように変わる .) 衛 星か軌道を半周したとき, ベクトルの先端は円周上を 1 周 する.第 8 図の成長率べクトルについては, 第 9 図のよう に“一定ベクトル”と“旋回ベクトル”に分解すると考えや すい，一定ベクトルは長さ $K / 2$ をもち，光の先端を起点 とする旋回ベクトルは，(1)，(2)，(3)，(4)のように円周 をな兮って動く，一定ベクトルが表す成長率によって生じ る中心の変位は, 時間とともに一樣に増していく .これを 永年成長と呼心゙ことにすれば, 永年成長率は $K / 2$ に等し い.一方, 旋回ベクトルが表す成長率によって生じる中心 の変位は, 円を描いて動く. 弚の動きは, 衛星か軌道を半 周するごとに，同じ円をくり返し描く．よって光の動きは 一定の限度内にとどまるから，長期的ならるまいを調べる 際には考えなくてよい．

つぎに, 力 $F$ による増速の，進行方向への成分について 考える.第 10 図において, 衛星が (1)の位置にあるとする と，時間 $\Delta t$ の間に

$$
\Delta v=F \Delta t \cos \theta
$$

という増速が進行方向に生じる.(衛星の公転角 $\theta$ は, 力 $F$ に垂直な方向を基準として測った ) この増速は，(7) 式に 従って軌道半径を変化させる. 兴の変化を, 軌道 1 周回に わたって積算すれば，(12) 式における $\cos \theta$ の周期性のた めに零になる．ゆえに軌道半径に永年的な変化は起きない． 一方，第 2 図に見たメカニズムによって，中心は第 10 図 の $\mathrm{O}$ から変位して $\mathrm{O}_{1}$ に移り, 弚の変位の発生量は

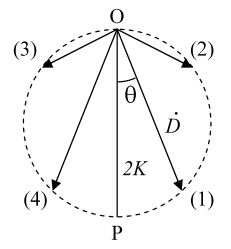

第 11 図 中心変位の成長率

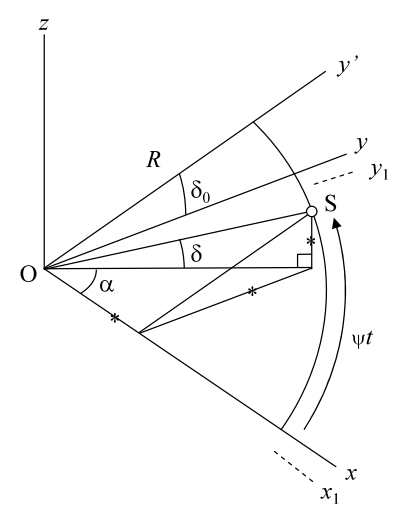

第 12 図 太陽 $\mathrm{S}$ の位置

$$
\Delta D=2 a \frac{\Delta v}{v}=\frac{2 a F}{v} \cos \theta \Delta t
$$

に等しい.よって変位 $D$ の成長率を

$$
\dot{D}=2 K \cos \theta
$$

と表せる .この成長率をべクトルで表すと，第 11 図の (1) に相当し, 弚の先端は長さ $2 K$ の線分 $\mathrm{OP}$ を直径とした円 の周上にある . 第 10 図にて衛星の位置が (2) , (3) , (4) と 進むと，第 11 图にてべクトルの先端は (2)，(3)，(4) と進 み, 衛星か軌道を半周したときべクトルの先端は円周上を 1 周する . ここでも成長率べクトルを，一定ベクトルと旋 回ベクトルに分解すると，一定ベクトルは長さ $K$ をもち， 従って永年成長率は $K$ に等しい。

以上, 中心の変位について見出した二つの永年成長率は, 合計で $(3 / 2) K$ ，すなわち

$$
\dot{D}=\frac{3 a F}{2 v}
$$

となり，成長の向きは力 $F$ の向きに垂直を指す．

ここまで, 力 $F$ は変わらないと仮定してきた . 現実に は，光れは太陽の位置に依存して変わる.地心 $\mathrm{O}$ から見る 太陽 S の位置を，第 12 図のように表す . $x-y$ 面は赤道面 に相当し， $z$ 軸は地球の北極を向き， $x$ 軸は春分点を指す． 太陽の方向は, $x-y$ 面からの離角 $\delta$ (赤緯)，および $x-y$ 面に沿って $x$ 軸から測る方位 $\alpha$ (赤径) で表す . $y$ 軸から $z$ 軸にむかって角度 $\delta_{0}=23.5$ 度だけ傾いた軸 $y^{\prime}$ をとり， $x-y^{\prime}$ 面上に半径 $R$ の円を描くと，兴の上を太陽は 1 年か かって 1 周する . 太陽は春分の日に $x$ 軸から出発し，時間 $t$ の後に周回角 $\psi t$ まで進む . 図中で“*”を付した長さに ついて，次の関係が成りたつ。 


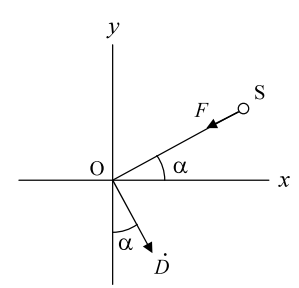

第 13 図 中心变位の成長率

$\cos \delta \cos \alpha=\cos \psi t$

$\cos \delta \sin \alpha=\sin \psi t \cos \delta_{0}$

$\sin \delta=\sin \psi t \sin \delta_{0}$

よって赤径 $\alpha$ と赤緯 $\delta$ は, 周回角が進むにつれて (14) 式 を介して変わる . このとき力 $F$ の大きさは

$$
F=F_{0} \cos \delta ; \quad F_{0}=C \frac{A^{\prime}}{M}
$$

と表される.$C$ は太陽光の強さによって決まる定数 $(4.56 \times$ $10^{-6}\left[\mathrm{~N} / \mathrm{m}^{2}\right]$ )， $A^{\prime}$ と $M$ は衛星の断面積と質量を表す .こ こで $A^{\prime}$ は, 衛星が光を反射することを考慮に入れた等価 的な断面積を表すもので, 幾何学的な断面積 $A$ に対して $A^{\prime}=(1+\eta) A$ という関係にある．もし衛星に入射した光

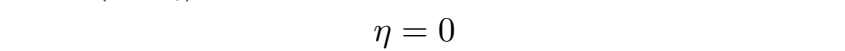
その度合いに応じて $\eta$ が大きくなるが 1 を超えることはな い. 実際の $\eta$ は表面の材質や形状によって決まり, 衛星に 固有な量として比 $A^{\prime} / M$ が定まる．厳密にいうと $A^{\prime}$ は， 衛星に入射する光の方向に依存して増減し得るが，ここで は近似的に $A^{\prime}$ が一定であるとおく.

さて, 上記の力 $F$ が引きおこす中心変位の成長率は, $(13)$ 式から

$$
\dot{D}=K \cos \delta
$$

となる．ただし定数を改めて

$$
K=\frac{3 a F_{0}}{2 v}=\frac{3 F_{0}}{2 \omega}
$$

とおいた . 力 $F$ によって生じる成長率の向きは, 第 13 図 に描くように太陽の赤径 $\alpha$ に依存する . 成長率 $(15)$ を $x$, $y$ 成分に分けて表し，(14) 式を適用すれば

$$
\begin{aligned}
& \dot{D}_{x}=K \cos \delta \sin \alpha=K \cos \delta_{0} \sin \psi t \\
& \dot{D}_{y}=-K \cos \delta \cos \alpha=-K \cos \psi t
\end{aligned}
$$

となって , これが中心の動きを定める . 春分の日に中心は 原点にあったとすると，弚の後の動きは次式に従う.

$$
\begin{aligned}
& D_{x}=D_{0} \cos \delta_{0}(1-\cos \psi t) \\
& D_{y}=-D_{0} \sin \psi t \quad \text { ただし } \quad D_{0}=\frac{K}{\psi}=\frac{3}{2 \psi \omega} C \frac{A^{\prime}}{M}
\end{aligned}
$$

中心の動きは 1 年間で第 14 図のように楕円を描く. 定数 として $\psi=1.99 \times 10^{-7} \mathrm{rad} / \mathrm{s}, \omega=7.29 \times 10^{-5} \mathrm{rad} / \mathrm{s}$ を与え, 衛星の一例として $A^{\prime} / M=0.01 \mathrm{~m}^{2} / \mathrm{kg}$ とすると， 楕円の長径は $2 D_{0}=9.4 \mathrm{~km}$ となる . 長径に比べて短径は $\cos \delta_{0}=0.92$ 倍に縮む．

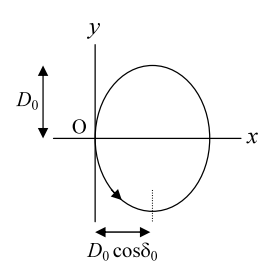

第 14 図 中心变位の 1 年間の動き

5. 太陽と月の引カによる摂動

前節まで, 軌道面内でおきる捸動を見てきた . 一方では， 軌道面の向きを変える捸動が太陽と月の引力によって生じ る . まず太陽の引力について調べるために , 地心 $\mathrm{O}$ から見 た太陽 S の位置を第 15 図のように表す. $z$ 軸は地球の北 極を向き，ここでは太陽が $x-z$ 面にあるように $x$ 軸をと る. 衛星は $x-y$ 面上の位置 $(x, y)$ にあるものとして, 衛 星から太陽に向かう引力の $z$ 成分を $F$ とおけば, これが 軌道面を変える捸動力として働く. 太陽の位置を $x=X$, $z=Z$ とすると,$F$ は

$$
F=\frac{\mu}{(X-x)^{2}+y^{2}+Z^{2}} \cdot \frac{Z}{\sqrt{(X-x)^{2}+y^{2}+Z^{2}}}
$$

と表せる ( $\mu$ は万有引力定数 $\times$ 太陽質量 $). \mathrm{O}$ から $\mathrm{S}$ への 距離 $R=\sqrt{X^{2}+Z^{2}}$ は， $x$ と $y$ に比べて十分に大きいか ら, (16) 式にて $x / R$ と $y / R$ の 1 次の項までとれば, 次 の近似が成りたつ。

$$
F=\frac{\mu Z}{R^{3}}+\frac{\mu Z}{R^{3}} \cdot \frac{3 X x}{R^{2}}
$$

右辺の第 1 項を $F_{0}$ と記すと， $F_{0}$ は地心 $\mathrm{O}$ が受ける力の $z$ 成分を表す. 弚の地心を軌道面は通っていなければなら ない.よって軌道面をまわ光うとするトルクを

$$
T=\left(F-F_{0}\right) \cdot x
$$

とおけば ,これは第 15 図にて $T$ と記したように,$y$ 軸まわ りのトルクを表す . (以下 , トルクおよび角運動量は , 衛星 の単位質量あたりの值を指すものとして扱う））衛星は半径 $a$ の円軌道を角速度 $\omega$ で周回するものとして , $x=a \cos \omega t$ とおけば，トルクの大きさは

$$
T=\frac{\mu Z}{R^{3}} \frac{3 X}{R^{2}} a^{2} \cos ^{2} \omega t
$$

に等しい．このトルクを衛星の軌道 1 周回にわたって平均 し，赤緯 $\delta$ を用いて $Z=R \sin \delta, X=R \cos \delta$ と記すと， 次のように表せる .

$$
T=\frac{3 \mu}{2 R^{3}} a^{2} \sin \delta \cos \delta
$$

一方， $x$ 軸まわりに生じるトルクは, 軌道 1 周回にわたり 平均すると対称性によって零になる .

さて衛星は角速度 $\omega$ で円運動するから，軌道面は角運動 


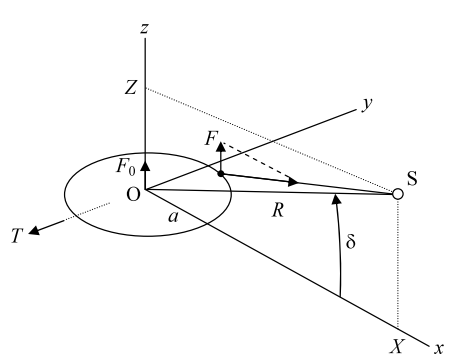

第15図 太陽引カが引きおこすトルク

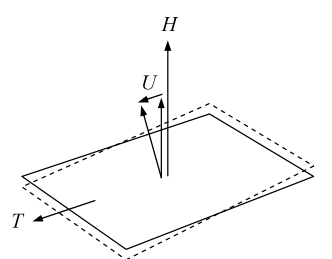

第16図 トルクによる軌道面の傾き

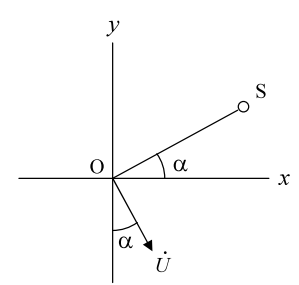

第 17 図軌道面傾斜の成長率

量 $H=a^{2} \omega$ をもつ. 弚の軌道面にトルク $T$ が働くと, 第 16 図に描くように軌道面の傾きが生じる.軌道面に設けた 単位法線の先端が変位する量 $U$ によって, 軌道面の傾きを 表すことにすれば， $U$ の成長率は

$$
\dot{U}=\frac{T}{H}=L \sin \delta \cos \delta
$$

に等しい.ただし定数を

$$
L=\frac{3 \mu}{2 R^{3} \omega}
$$

と記した .ここで座標軸のとりかたを第 12 図にならうよ うに変更して,$x$ 軸は春分点を指すようにする．弚の座標 系で，(17) 式による傾きの成長率を表すと第 17 図のよう になって，成長率の $x, y$ 成分を次のように表せる.

$$
\begin{aligned}
& \dot{U}_{x}=L \sin \delta \cos \delta \sin \alpha \\
& \dot{U}_{y}=-L \sin \delta \cos \delta \cos \alpha
\end{aligned}
$$

これに (14) 式を適用して，次式を得る .

$$
\begin{aligned}
& \dot{U}_{x}=L \sin \delta_{0} \cos \delta_{0}\left(\frac{1}{2}-\frac{\cos 2 \psi t}{2}\right) \\
& \dot{U}_{y}=-L \sin \delta_{0} \frac{\sin 2 \psi t}{2}
\end{aligned}
$$

これから $U$ の動きを求めると， 2 種類の動きか現れる。ひ とつは (18) 式の右辺第 1 項から生じる永年成長

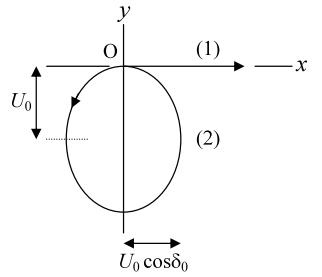

第 18 図軌道面傾斜の種類別成長

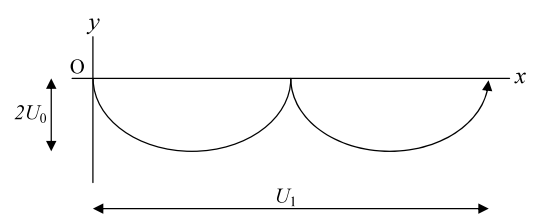

第 19 図軌道面傾斜の年間成長

$$
U_{x}=(L / 2) \sin \delta_{0} \cos \delta_{0} \times t \quad[\mathrm{rad}]
$$

で，第 18 図の (1) に相当する . 定数として $\omega=7.29 \times$ $10^{-5} \mathrm{rad} / \mathrm{s}, \psi=1.99 \times 10^{-7} \mathrm{rad} / \mathrm{s}, \delta_{0}=23.5 \mathrm{deg}$, $R=1.50 \times 10^{8} \mathrm{~km}, \mu=1.33 \times 10^{11} \mathrm{~km}^{3} / \mathrm{s}^{2}$ を与えると， 1 年間あたりの成長は 0.27 度に等しい .一方，(18) 式の右 辺第 2 項および (19) 式からは, 半年を周期とする動きが 生じる . 春分の日に, 軌道面の傾きは零であったとすると， 兴の後の動きは次式に従う.

$$
\begin{aligned}
& U_{x}=-U_{0} \cos \delta_{0} \sin 2 \psi t \\
& U_{y}=U_{0}(\cos 2 \psi t-1) \quad \text { ただし } \quad U_{0}=\frac{L}{4 \psi} \sin \delta_{0}
\end{aligned}
$$

この周期的な動きは , 半年で第 18 図の (2) のように楕円 を描く．以上， 2 種類の動きを重ねあわせると， 1 年間で第 19 図のような軌跡を描く. 年間の永年成長 $U_{1}$ に対して， 横の振れ幅 $2 U_{0}$ が成す比率を次のように算出できる (1 年 を $Y$ とおく).

$$
\begin{aligned}
2 U_{0} / U_{1} & =\frac{2 U_{0}}{(L / 2) \sin \delta_{0} \cos \delta_{0} \times Y} \\
& =\frac{1}{\psi Y \cos \delta_{0}} \\
& =\frac{1}{2 \pi \cos \delta_{0}} \\
& =0.17
\end{aligned}
$$

月の引力についても , 以上と同じ導出を適用できる.第 12 図と第 15 図において $\mathrm{S}$ をと見なし，定数には $R=3.84 \times$ $10^{5} \mathrm{~km}, \psi=2.66 \times 10^{-6} \mathrm{rad} / \mathrm{s}, \mu=4.90 \times 10^{3} \mathrm{~km}^{3} / \mathrm{s}^{2}$ を与える. 光して月が赤道面を南から北へよぎった後, 1 か 月間に描く軌跡が第 19 図に相当する. そのさい注意とし て, 第 12 図における角度 $\delta_{0}$ は月については一定でなく， 18.3 度と 28.6 度の間を周期 18.6 年で往き来する .よって $(20)$ 式による永年成長は $\delta_{0}$ に依存して変わり, 1 年間での 成長は 0.48 度と 0.67 度の間にある . 振れ幅の比率も $(21)$ 式中の $\delta_{0}$ に応じて変わる.さらに注意として, 太陽の場合 には，第 12 図にて赤道面をよぎる交点が必ず $x$ 軸上にあ 
るが, 月の場合には光の交点が $x$ 軸から離れ, 弚の離れ方 は赤径で \pm 13 度の範囲を周期 18.6 年で往き来する .この ことを反映するとすれば, 第 12 図の $x-y$ 面上で, 例えば $x_{1}$ 軸と $y_{1}$ 軸を改めて $x$ 軸と $y$ 軸とおくような座標軸の 回転を施すとよく，回転の角度は \pm 13 度の範囲内にある 対応して第 17 図，第 18 図，第 19 図の各表示もまた，同 じ角度の回転を時計または反時計まわりに施したものが実 際の現象を表す。

太陽引力による摂動と, 月の引力による捸動は別々に求 めて重ねあわせればよく, 光の結果, 年間で 0.75 度ないし 0.94 度の永年成長が現れる。

\section{6. 補足}

以上の議論から , 地球の形 , 太陽光の圧力 , 太陽・月の引 カによって摂動が生じる過程が明らかになった .これらの 摂動は, 衛星の静止を失わせるように働くから, 静止を保 つには対策を講じなければならない．第 6 図が表す経度の 摂動への対策としては，図中の “*” のように軌道半径を変 えることで, 経度の動きを破線のように変えるとよく，光 のような軌道制御を適切な頻度で行う.軌道半径を変える には, 第 2 図に示す $\Delta v$ を与えるが, 弚れは同時に中心の 変位を引きおこす. 光の変位と, 第 14 图が示す法則とを勘 案すれば，離心率の増大を最小限におさえるような制御を 工夫できる、第 19 図が表す永年成長に対しても，軌道面 の傾きを永年成長の逆向きに引きもどすような制御を適切 な頻度で行う.第 6 図，第 14 図，第 19 図が表すような攝 動が存在するという事実は, 静止衛星の関係方面に広く知 られていよう. しかし光れらの摂動法則をまとめて解析的 に, 分かりやすく導いた資料は見あたらなく，この点に本 報告の意義があると思われる .

導出した捸動法則については, 弚れ皆れ数值積分と比較 したところ，以下のような一致度であった . 経度の摂動に ついては, 第 3 節の末尾に記した例にならい東経 120 度に ある衛星を想定して，第 6 図に相当する経度の動きを数値 積分で 20 日にわたり生成する. 弚れに 2 次カーブを当て
はめて経度の加速度を読みとり，光れを末尾に記した理論 值と比べると，違いは $0.00001 \mathrm{deg} / \mathrm{day}^{2}$ をこえない．太 陽光の圧力については，第 14 图の表示に即した 1 年間の

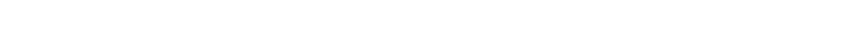
$400 \mathrm{~m}$ をこえない . 太陽の引力については, 第 19 図に即し て 1 年間の動きを生成したとき, 理論と数值積分での違い は 0.003 度をこえない . 月の引力については, 第 12 図にお ける “座標軸の回転”を考慮に入れた上で, 第 19 図に即し て 1 か月間の動きを生成したとき, 理論と数值積分での違 いは 0.001 度をこえない.これらの一致度が, 理論の正し さの目安を示す .

第 3 節においては, 衛星の位置が地球に対して固定され ていることを前提とした . この前提は，第 4 節と第 5 節で は必ずしも必要とされない . 第 4 節と第 5 節に述べた導出 は, 衛星が円軌道にあり, 弚の軌道面が赤道面に近いとい う場合について一般に適用できる。

$$
\text { 7. むす び }
$$

静止軌道にある衛星に対し, 静止を失わせるように㗢く 摂動として代表的な，

・地球の形による衛星経度の変化

·太陽光の圧力による離心率の成長

・太陽と月の引力による軌道面の傾き

について, 軌道変化の法則を簡易な理論によって導出した。 導出には図式的な解法を用いた結果, 摂動の物理的ないし 幾何学的な意味が明らかになった . 対象とした捸動はどれ も，実際に静止衛星の軌道を保持するうえで考慮から欠か せない . 本報告によれば, 静止衛星の軌道保持の背景をなす 摂動現象について，平易かつ定量的な解釈を提供できよう。

\section{参 考 文 献}

1) Brouwer, D. and Clemence, G. M.: Methods of Celestial Mechanics, Academic Press, New York, 1961.

2) 木下 宙: 天体と軌道の力学, 東京大学出版会, 東京, 1998 , pp. $135-219$.

3) 飯田尚志編著: 衛星通信, オーム社, 東京, 2003, pp. 56-65. 